\title{
Anti-EGFR targeted monoclonal antibody isotype influences anti-tumor immunity in head and neck cancer patients
}

\author{
Sumita Trivedi ${ }^{*}$, Raghvendra M Srivastava ${ }^{1}$, Fernando Concha-Benavente ${ }^{2}$, Tatiana M Garcia-Bates ${ }^{1}$, Jing Li \\ Robert L Ferris ${ }^{1}$
}

From 30th Annual Meeting and Associated Programs of the Society for Immunotherapy of Cancer (SITC 2015) National Harbor, MD, USA. 4-8 November 2015

EGFR is frequently overexpressed on several cancers, and two targeted antibodies are FDA approved but differ by isotype. Cetuximab (IgG1 isotype) has been shown to be effective at both inhibiting downstream signaling of EGFR and activating anti-tumor, cellular immune mechanisms. While panitumumab (IgG2 isotype) can inhibit downstream EGFR signaling similar to cetuximab, panitumumab might also induce antibody-dependent cell cytotoxicity (ADCC) or adaptive immunity. We sought to investigate the cellular immunity specifically activated by cetuximab or panitumumab showing that both mAb primarily activate NK cells, although cetuximab was significantly more potent than panitumumab. We also observed that although panitumumab may activate monocytes through the CD32 (Fc $\gamma$ RIIa) receptor, neither $\mathrm{mAb}$ activated monocytes sufficiently to mediate ADCC. Cetuximab enhanced DC maturation to a greater extent than panitumumab, corresponding with improved cross presentation of tumor antigen by cetuximab compared with panitumumab. Indeed, improved adaptive immune responses with increased EGFR-specific cytotoxic $\mathrm{CD}^{+} \mathrm{T}$ cells were present in patients treated with cetuximab compared to those treated with panitumumab. These results suggest that although panitumumab effectively inhibits EGFR signaling to a similar extent as cetuximab, it is less effective at mediating anti-tumor, cellular immune mechanisms which may be crucial for effective therapy for HNSCC.

\section{Authors' details}

${ }^{1}$ University of Pittsburgh Cancer Institute, Pittsburgh, PA, USA. ${ }^{2}$ Department of Immunology, University of Pittsburgh, Pittsburgh, PA, USA.

Published: 4 November 2015

doi:10.1186/2051-1426-3-S2-P316

Cite this article as: Trivedi et al: Anti-EGFR targeted monoclonal antibody isotype influences anti-tumor immunity in head and neck cancer patients. Journal for ImmunoTherapy of Cancer 2015 3(Suppl 2): P316.

'University of Pittsburgh Cancer Institute, Pittsburgh, PA, USA

Full list of author information is available at the end of the article

Submit your next manuscript to BioMed Central and take full advantage of:

- Convenient online submission

- Thorough peer review

- No space constraints or color figure charges

- Immediate publication on acceptance

- Inclusion in PubMed, CAS, Scopus and Google Scholar

- Research which is freely available for redistribution
() Biomed Central 